\title{
Inisiasi Kampung Komplementer Untuk Optimalkan Kesehatan Ibu dan Anak
}

\author{
Ester Ratnaningsih*1, Lenna Maydianasari ${ }^{2}$, Rahayu Widaryanti ${ }^{3}$, Muflih $^{4}$ \\ 1,2,3 Kebidanan, Universitas Respati Yogyakarta \\ ${ }^{4}$ Keperawatan, Universitas Respati Yoyakarta \\ *E-mail: esterratna@respati.ac.id
}

\begin{abstract}
The majority of mothers who have toddlers in Karangrejo Sub-Village, Karangnongko, Tirtomartani Village, Kalasan Subdistrict come to the baby shaman to massage the baby and provide herbs to increase appetite in her child. The public also does not have knowledge of complementary therapies to address mild health complaints without chemical drugs such as cupping, accupoint and herbal therapy. The purpose of community service is to initiate the formation of complementary villages in Karangrejo Sub-Village. The activities carried out are complementary cadre training, baby healthy food movement, toddler and breastfeeding, healthy toddler movement and healthy living community movement with the use of herbs. Monitoring and evaluation are carried out with assistance to motivate the sustainability of the program. The result achieved is (1) The partner has formed and has a complementary village manager; (2) The partners have complementary cadres (3) The partners have carried out complementary village activities, namely healthy food movements for infants, toddlers and nursing mothers, monitoring growth and healthy community movements with the use of herbal plants.
\end{abstract}

Keywords: village, complementary, health, mother, child

\begin{abstract}
Abstrak
Mayoritas ibu yang memiliki balita di Dusun Karangrejo, Padukuhan Karangnongko, Desa Tirtomartani, Kecamatan Kalasan datang ke dukun bayi untuk memijatkan bayinya dan memberikan ramuan herbal untuk menambah nafsu makan pada anaknya. Masyarakat juga belum memiliki pengetahuan tentang terapi komplementer untuk mengatasi keluhan kesehatan ringan tanpa obat-obat kimia seperti bekam, accupoint dan terapi herbal. Tujuan pengabdian kepada masyarakat ini yaitu menginisiasi pembentukan kampung komplementer di Dusun Karangrejo. Kegiatan yang dilaksanakan adalah pelatihan kader komplementer, gerakan makanan sehat bayi, balita dan menyusui, gerakan bayi balita sehat dan gerakan masyarakat hidup sehat dengan pemanfaatan herbal. Monitoring dan evaluasi dilaksanakan dengan pendampingan untuk memotivasi keberlanjutan program. Hasil dicapai yaitu (1) Mitra telah membentuk dan memiliki pengurus kampung komplementer; (2) Mitra memiliki kader komplementer (3) Mitra telah melaksanakan kegiatan kampung komplementer yaitu gerakan makanan sehat untuk bayi, balita dan ibu menyusui, pemantauan tumbuh kembang serta gerakan masyarakat sehat dengan pemanfaatan tanaman herbal.
\end{abstract}

Kata kunci: kampung, komplementer, kesehatan, ibu, anak

\section{PENDAHULUAN}

Kesehatan Ibu dan Anak (KIA) menjadi target dalam tujuan pembangunan SDGs (Sustainable Development Goals) khususnya pada poin ketiga yaitu memastikan hidup sehat dan meningkatkan kesejahteraan untuk semua di segala usia (ensure healthy lives and promote well-being for all at all ages). Masalah kesehatan ibu dan anak di Kabupanten Sleman masih tergolong kompleks, angka kematian bayi meningkat dibanding tahun 2016. Jumlah kematian bayi pada tahun 2016 sebanyak 44 kasus dari 14.139 kelahiran hidup dengan AKB 3,11 per 1.000 kelahiran hidup (KH), sedangkan jumlah kematian bayi tahun 2017 sebanyak 59 kasus dari 14.025 kelahiran hidup dengan AKB 4,4 per 1000 KH. (Dinkes Kabupaten Sleman, 2018). Selain AKB masalah gizi juga menjadi prioritas penting, hasil pemantauan status gizi balita di Kabupaten Sleman tahun 2015 diperoleh 12,86\% stunting, 7,53\% underweight, 6,14\% overweight dan 3,57\% wasting. Kecamatan Kalasan merupakan kecamatan yang 
memiliki kejadian stunting tertinggi ke dua pada tahun 2017 yaitu sebanyak 20,71\%. Dari Hasil penelitian yang dilakukan di Puskesmas Kalasan pada tahun 2019 diketahui bahwa $47 \%$ balita yang mengalami stunting dikarenakan praktik pemberian PMBA yang tidak tepat. (Widaryanti, 2019; Dinkes Kabupaten Sleman, 2018).

Salah satu strategi pembangunan kesehatan adalah mendorong masyarakat agar mampu memelihara kesehatannya, serta mengatasi gangguan kesehatan ringan secara mandiri melalui kemampuan asuhan mandiri. Secara bertahap mulai tahun 2015 sampai dengan tahun 2019 diharapkan 75\% puskesmas di Kabupaten/Kota melakukan pembinaan pelayanan kesehatan tradisional, termasuk didalamnya puskesmas melakukan pembinaan terhadap kelompok asuhan mandiri dalam memanfaatkan tanaman obat keluarga (TOGA) dan Keterampilan (akupresur) melalui pelaksanaan asuhan mandiri berarti kita telah berupaya merubah paradigma pengobatan kuratif menjadi promotif dan preventif, yang bermanfaat untuk efisiensi dan efektivitas bagi keluarga dalam menjaga kesehatan diri sendiri dan keluarganya. Sesuai dengan kebijakan Kementerian Kesehatan, diharapkan kunjungan masyarakat ke Puskesmas merupakan kunjungan dalam rangka konsultasi kesehatan bukan untuk mengobati sakitnya.

Mayoritas penduduk di Dusun Karangrejo Padukuhan Karangnongko Desa Tirtomartani, Kecamatan Kalasan bermata pencaharian sebagai petani $(67,61 \%)$. Dusun Karangrejo memiliki berbagai potensi sumber daya alam yang cukup baik, ditunjang dengan kondisi tanah yang subur dibuktikan dengan luasnya area persawahan dan perkebunan. Namun yang sangat disayangkan, masyarakat belum mengoptimalkan penggunaan sumber daya di daerah tersebut untuk menanam dengan tanaman herbal untuk terapi pendamping/komplementer dalam meningkatkan kesehatan masyarakat khususnya ibu dan anak. Masyarakat juga masih memiliki kepercayaan tinggi terhadap dukun bayi, kebanyakan ibu yang memiliki balita mengunjungi dukun bayi untuk memijatkan bayinya. Namun sayangnya dukun bayi tersebut belum mengikuti pelatihan dari tenaga kesehatan, keterampilan memijatnya hanya berdasarkan turun temurun yang dipelajari secara otodidak sehingga masih terdapat beberapa tehnik yang masih bertentangan dengan kesehatan. Selain pijat bayi kepercayaan masyarakat lainnya yaitu memberikan ramuan herbal (cekok) untuk menambah nafsu makan pada anaknya. Pada dasarnya memijat bayi ataupun memberikan jamu cekok baik untuk memelihara kesehatan namun cara yang dilakukan harus sesuai dengan evidence based yang ada sehingga mengurangi risiko cidera maupun trauma pada bayi atau anak. Demikian halnya dengan ibu hamil, ibu bersalin dan menyusui belum memiliki pengetahuan yang cukup untuk mengatasi keluhan kesehatan secara mandiri dengan meminimalkan obat-obat kimia.

Melihat permasalahan tersebut peran kader sangat strategis untuk mengatasi permasalahan tersebut. Keuntungan kader kesehatan di masyarakat lebih memudahkan menyampaikan informasi kesehatan karena kedekatan secara psikologis maupun waktu. Hal ini didukung penelitian di Kabupaten Blora pada tahun 2010 yang menyatakan bahwa pendekatan verbal secara individual oleh kader kesehatan lebih efektif dalam meningkatkan pengetahuan deteksi dini penyakit diare pada balita dan keterampilan penerapan terapi rehidrasi oral. Hasil penelitian Subagyo (2010) juga menyatakan bahwa kemampuan kader mempunyai hubungan yang signifikan dengan keberhasilan program posyandu. Kondisi ini memperlihatkan peran penting kader posyandu sebagai garda terdepan dalam pelayanan kesehatan. Oleh sebab itu peningkatan pengetahuan keterampilan dari kader sangat diperlukan untuk mendukung program kesehatan (Dinkes Kabupaten Sleman, 2018; Utami, 2011; Subagyo, 2010).

Berdasarkan latar belakang diatas, maka tim pengabdi mendayagunakan potensi sumber daya alam dan sumber daya yang ada di Dusun Karangrejo dengan kegiatan pengabdian kepada masyarakat yang bertujuan untuk menginisiasi pembentukan Kampung Komplementer. Kampung komplementer adalah satuan wilayah setingkat RW, Dusun atau yang setara dengan kriteria tertentu dimana terdapat keterpaduan program kesehatan dan terapi komplementer dalam upaya meningkatkan kualitas hidup keluarga dan masyarakat. Tujuan Kampung Komplementer adalah meningkatkan kualitas hidup keluarga dan masyarakat dengan program pembentukan kampung komplementer yang terintegrasi dengan upaya kesehatan masyarakat lainnya. Sasaran dari Kampung Komplementer adalah keluarga ibu hamil dan menyusui, bayi dan anak balita, kader posyandu dan masyarakat. 


\section{METODE}

Kegiatan pengabdian kepada masyarakat ini terdiri dari tahap survei, pelaksanaan serta monitoring dan evaluasi. Tahap Survei dilakukan dengan meninjau lokasi pengabdian kepada masyarakat yaitu Dusun Karangrejo, Desa Tirtomartani, Kecamatan Kalasan, Kabupaten Sleman, sekaligus koordinasi dan sosialisasi dengan pemangku wilayah dalam hal ini adalah Kepala Padukuhan Karangnongko.

Tahap pelaksanaan kegiatan pengabdian kepada masyarakat meliputi :

1. Pembentukan Pengurus dan Pemilihan Kader Komplementer karena pengelolaan kampung komplementer memerlukan pengurus atau pokja yang disepakati masyarakat. Pembentukan pengurus kampung komplementer dan kader komplementer melalui musyawarah.

2. Pelatihan Kader Komplementer meliputi Bekam, Accupoint, Pijat Bayi, PMBA dan Terapi Herbal.

3. Pendataan keluarga dengan Ibu hamil, ibu menyusui, bayi dan balita.

4. Gerakan Makanan Sehat Bayi, Balita, Ibu Hamil dan Menyusui

5. Gerakan Sukses ASI Eksklusif

6. Gerakan Masyarakat Hidup Sehat Dengan Pemanfaatan Herbal

7. Lounching Kampung Komplementer oleh pemangku wilayah disaksikan perwakilan warga Dusun Karangrejo dan kader komplementer.

Tahap monitoring dilakukan dengan kegiatan pendampingan dan evaluasi dilaksanakan pasca pelaksanaan kegiatan dengan pre dan post test. Kegiatan monev bertujuan untuk keberlangsungan program dengan pendampingan kader dan memotivasi kader sebagai penggiat kampung komplementer.

\section{HASIL DAN PEMBAHASAN}

Pelaksanaan dan hasil kegiatan pengabdian kepada masyarakat diuraikan sebagai berikut:

1. Kegiatan Sosialisasi, Pemilihan Pengurus dan Kader Komplementer

Pengelolaan kampung komplementer memerlukan pengurus yang disepakati masyarakat, maka pada awal kegiatan dibentuk pengurus kampung komplementer pada hari Sabtu, 26 September 2020 yang terdiri dari Ketua, Sekretaris dan Bendahara

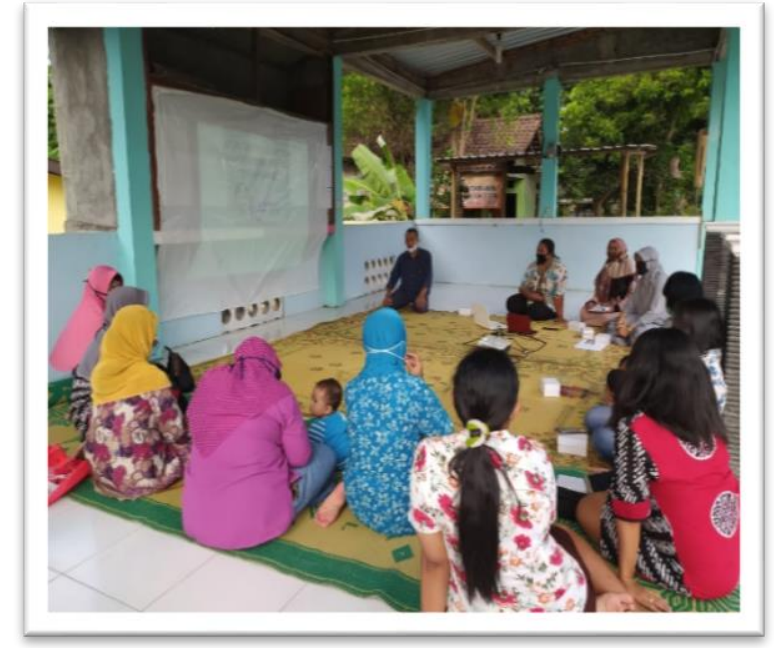

\section{Gambar 1. Sosialisasi, Pemilihan Pengurus dan Kader Kampung Komplementer}

Selain pemilihan pengurus, pada waktu yang sama juga dilaksanakan pemilihan kader komplementer. Pemilihan Kader komplementer ini dengan musyarawah dan bersifat sukarela dari warga yang bersedia menjadi kader komplementer sejumlah 19 orang.

2. Kegiatan Pelatihan Kader Komplementer

Kemampuan kader mempunyai hubungan yang signifikan dengan keberhasilan program posyandu. Kondisi ini memperlihatkan peran penting kader posyandu sebagai garda terdepan dalam 
pelayanan kesehatan. Oleh sebab itu peningkatan pengetahuan keterampilan dari kader sangat diperlukan untuk mendukung program kesehatan (Dinkes, 2018, Utami, 2011, Subagyo, 2010). Demikian halnya dengan program kampung komplementer, peran kader sangat penting sehingga tim pengabdi memberikan pelatihan kader komplementer. Pelatihan kader komplementer ini dibagi 2 kelompok yaitu kelompok 1 (hari pertama) sebanyak 9 orang dan kelompok 2 (hari kedua) sebanyak 16 orang. Materi pelatihan hari pertama yaitu pijat bayi, makanan pendamping ASI lokal dan ASI booster alami. Sedangkan materi pelatihan hari kedua yaitu bekam, accupoint dan terapi herbal.
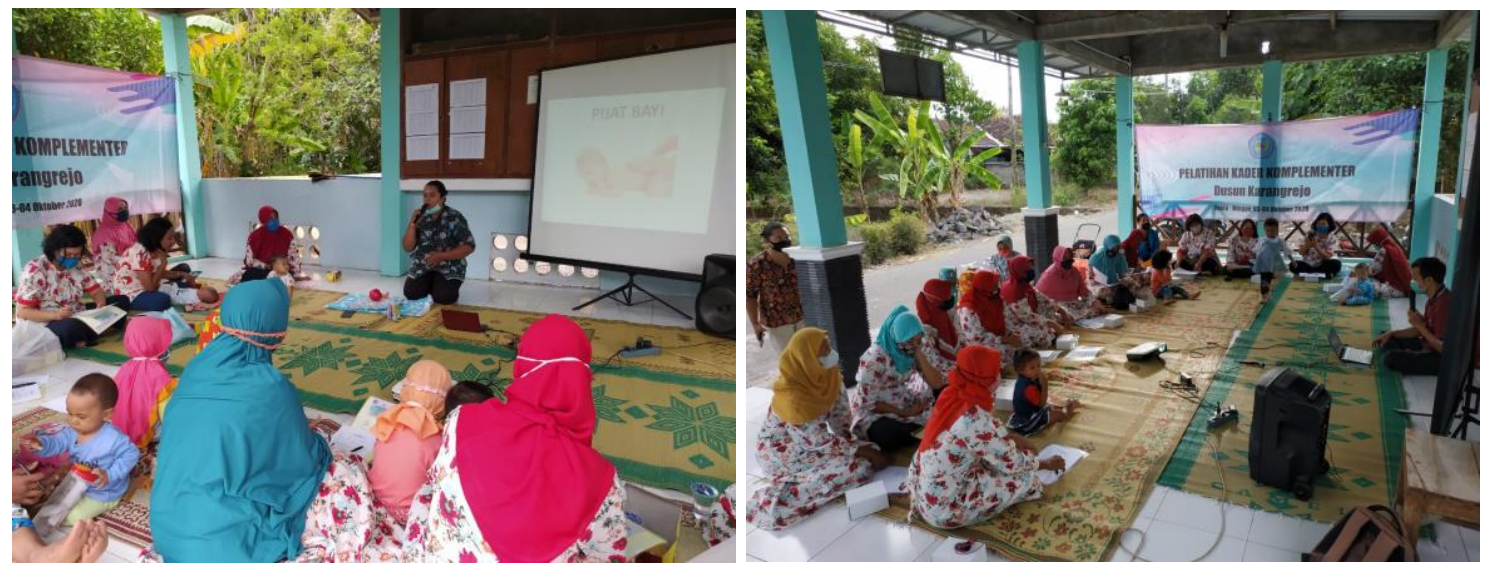

Gambar.2 Pelatihan Kader Komplementer

Selama pelatihan, tim pengabdi melakukan evaluasi pengetahuan peserta pelatihan dengan pre test, post test. Hal ini didukung oleh hasil penelitian Damayanti (2017) yang membuktikan bahwa metode pre test dan post test dapat digunakan sebagai indikator keberhasilan penyuluhan. Penilaian pengetahuan pada kegiatan ini dikategorikan menjadi 3 kategori yaitu baik (skor 75\%-100\%), cukup (skor 55\%-74\%) dan kurang (skor <55\% ). Hasil pre dan post test pada pelatihan kader komplementer hari pertama disajikan pada tabel 1.berikut ini:

Tabel 1. Hasil Pre Test dan Post Test Pelatihan Kader Hari Pertama

\begin{tabular}{lcccc}
\hline \multirow{2}{*}{\multicolumn{1}{c}{ Pengetahuan Peserta Pelatihan }} & \multicolumn{2}{c}{ Pre Test } & \multicolumn{2}{c}{ Post Test } \\
\cline { 2 - 5 } & f & $\%$ & f & $\%$ \\
\hline Kurang & 1 & 11,1 & 0 & 0 \\
Cukup & 5 & 55,6 & 0 & 0 \\
Baik & 3 & 33,3 & 9 & 100 \\
\hline Jumlah & 9 & 100 & 9 & 100 \\
\hline
\end{tabular}

Tabel 1 menunjukkan hasil pre test paling banyak peserta pelatihan memiliki pengetahuan cukup $(55,6 \%)$ tentang materi pijat bayi, makanan pendamping ASI lokal dan ASI Booster alami. Hasil post test menunjukkan peningkatan pengetahuan menjadi 100\% kategori baik. Hasil pre dan post test pada pelatihan kader komplementer hari kedua dapat dilihat pada tabel 2. berikut ini:

Tabel 2. Hasil Pre Test dan Post Test Pelatihan Kader Hari Kedua

\begin{tabular}{lcccc}
\hline \multirow{2}{*}{ Pengetahuan Peserta } & \multicolumn{3}{c}{ Pre Test } & \multicolumn{2}{c}{ Post Test } \\
\cline { 2 - 5 } & $\mathbf{f}$ & $\boldsymbol{\%}$ & $\mathbf{f}$ & $\%$ \\
\hline Kurang & 10 & 62,5 & 0 & 0 \\
Cukup & 5 & 31,2 & 7 & 43,7 \\
Baik & 1 & 6,3 & 9 & 56,3 \\
\hline Jumlah & 16 & 100 & 16 & 100 \\
\hline
\end{tabular}


Hasil pre test pelatihan kader hari kedua menunjukkan sebanyak 62,5\% kader memiliki pengetahuan kurang dan hanya 6,3\% yang memiliki pengetahuan baik. Kemudian diakhir sesi pelatihan dilakukan post test didapatkan hasil yaitu pengetahuan kader meningkat sebanyak $56,3 \%$ memiliki tingkat pengetahuan baik namun masih ada 43,7\% memiliki pengetahuan yang cukup. Melihat hasil evaluasi pengetahuan kader pasca pelatihan ini menunjukkan adanya kesiapan kader menjadi penggerak kampung komplementer.

Selain hasil evaluasi peserta kegiatan pelatihan dengan pre dan post test, pada pelatihan kader komplementer hari pertama juga dievaluasi penyelenggaraan kegiatan yang disajikan pada diagram 1. Sebagai berikut:

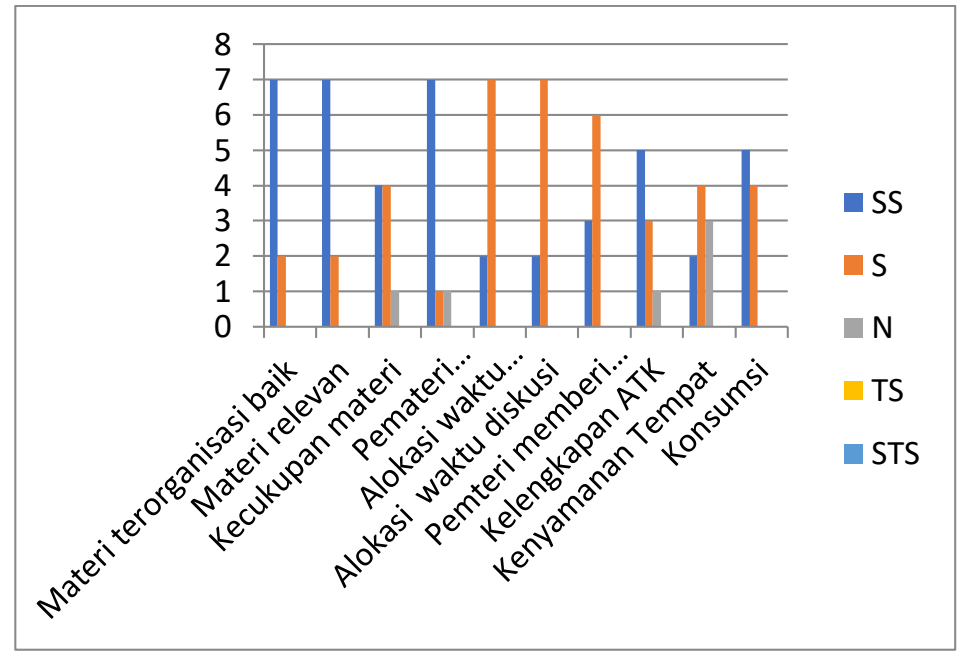

\section{Gambar 3. Evaluasi Pelatihan Kader Komplementer Hari Pertama}

Berdasarkan diagram di atas, dapat dilihat hasil evaluasi pelatihan kader komplementer hari pertama menunjukkan kepuasan terhadap pelatihan kader hari pertama, hal ini dibuktikan dari hasil evaluasi lebih dari 50\% sangat setuju untuk tiap item penilaian. Namun ada item yang memperoleh nilai kurang adalah kenyamanan tempat, karena tempat pertemuan di Balai Pertemuan RT 05/RW 28 Karangrejo berada di pinggir jalan, sehingga agak terganggu ketenangan dalam mendengarkan materi.

Hasil evaluasi kegiatan pelatihan kader komplementer hari kedua dapat dilihat pada gambar 4 di bawah ini:

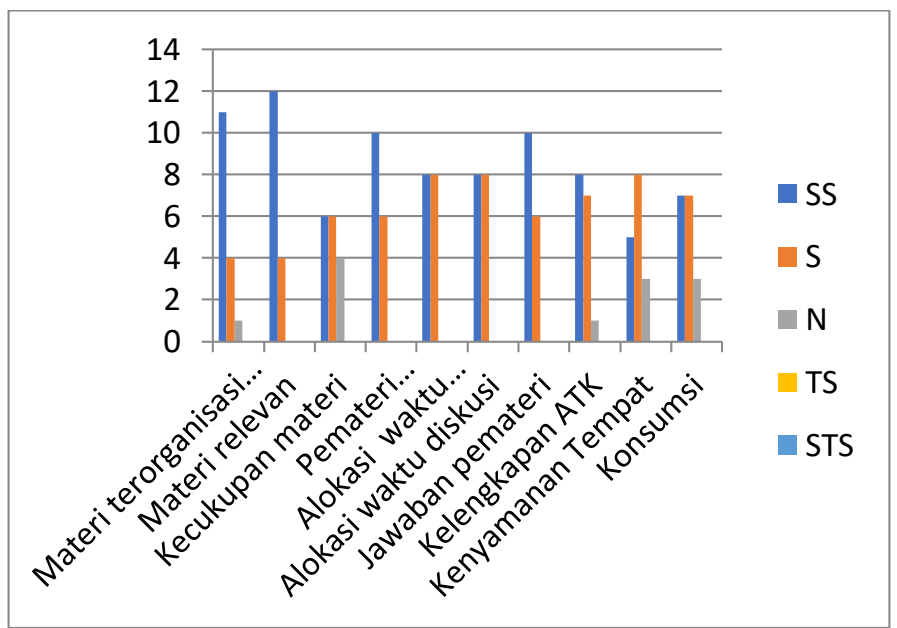

Gambar 4. Evaluasi Pelatihan Kader Komplementer Hari Kedua 
Gambar 4 menunjukkan hasil evaluasi pelatihan kader komplementer hari kedua, peserta cukup puas dengan penyelenggaraan pelatihan kader hari kedua ini dibuktikan dari hasil evaluasi lebih dari $50 \%$ menilai sangat setuju untuk tiap item penilaian. Peserta menilai materi yang diberikan belum cukup karena keterbatasan waktu, hal ini menunjukkan antusiasme peserta.

3. Pendataan keluarga dengan ibu hamil, ibu menyusui serta bayi dan balita

Pendataan dilaksanakan pada tanggal 6 Oktober 2020 kepada kader posyandu Dusun Karangrejo. Pendataan ini dilakukan untuk menentukan sasaran kegiatan kampung komplementer. Hasil pendataan yaitu tidak ada ibu hamil, jumlah ibu menyusui 8 orang, bayi 8 dan balita sebanyak 12. Dari hasil pendataan tersebut, tidak ada sasaran kegiatan untuk ibu hamil di Dusun Karangrejo sehingga untuk kegiatan gerakan makanan sehat bagi ibu hamil tidak dilaksanakan.

\section{Gerakan Makanan Sehat Bayi dan Balita}

Kegiatan ini dilaksanakan pada tanggal 18 Oktober 2020 bersamaan dengan kegiatan posyandu Dusun Karangrejo. Gerakan makanan sehat bagi bayi dan balita diawali dengan penyuluhan dan praktik membuat makanan sehat 4 bintang sesuai rekomendasi World Health Organization (WHO). Penyuluhan kesehatan merupakan salah satu cara untuk menambah pengetahuan dan kemampuan individu atau kelompok melalui pembelajaran (Kemenkes RI, 2011). Tujuan penyuluhan adalah untuk mengubah atau mempengaruhi perilaku responden agar lebih mandiri untuk mencapai hidup sehat.

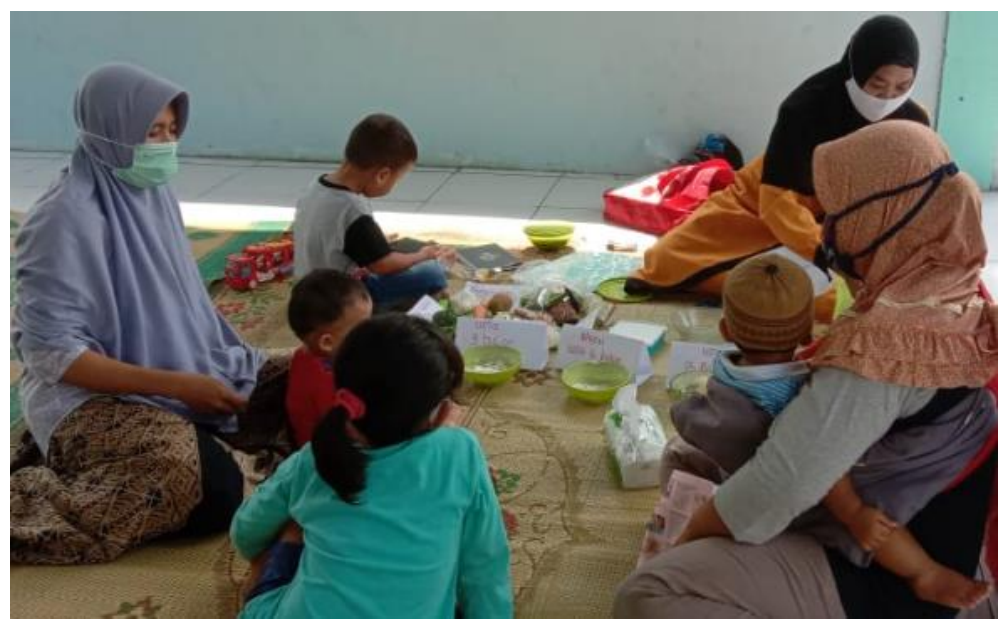

\section{Gambar 5. Penyuluhan dan Praktik Pemberian Makan Bayi dan Anak (PMBA)}

Dengan penyuluhan PMBA diharapkan ibu balita dan balita memiliki perilaku yang sehat dalam praktik pemberian makan pada bayi atau balitanya sehingga dapat mencegah terjadinya stunting. Hal ini sangat beralasan karena Kecamatan Kalasan merupakan kecamatan yang memiliki kejadian stunting tertinggi pada tahun 2016 yaitu sebanyak 22,30\%. Dari hasil penelitian yang dilakukan di Puskesmas Kalasan pada tahun 2019 diketahui bahwa 47\% balita yang mengalami stunting dikarenakan praktik pemberian PMBA yang tidak tepat (Widaryanti, 2019, Dinkes Kabupaten Sleman, 2018).

Selain penyuluhan PMBA, pada kegiatan posyandu juga dilakukan pemantauan tumbuh kembang bayi dan balita yaitu berat badan, tinggi badan dan perkembangan dengan Kuesioner Pra Skrining Perkembangan (KPSP) dengan hasil sebagai berikut: 
Tabel 3. Hasil pemantauan tumbuh kembang bayi dan balita di Dusun Karangrejo

\begin{tabular}{lcccc}
\hline \multirow{2}{*}{ Indikator } & \multicolumn{2}{c}{ Normal } & \multicolumn{3}{c}{ Tidak Normal } \\
\cline { 2 - 5 } & & & \multicolumn{3}{c}{} \\
\hline BB/U & 10 & 83,3 & 2 & 16,7 \\
TB/U & 9 & 75 & 3 & 25 \\
Perkembangan (KPSP) & 12 & 100 & 0 & 0 \\
\hline
\end{tabular}

Hasil pemantauan tumbuh kembang pada tabel 3 menunjukkan dengan indikator berat badan dibandingkan umur $(\mathrm{BB} / \mathrm{U})$ ditemukan $83,3 \%$ pertumbuhan bayi/balita normal, sedangkan indikator tinggi badan dibandingkan umur (TB/U) menunjukkan $75 \%$ bayi/balita pertumbuhannya normal. Namun demikian masih ditemukan bayi/balita dengan tidak normal dengan berat badan kurang $(16,7 \%)$ dan tinggi badan pendek (stunting) sebanyak 25\%. Angka ini memang tidak sebesar temuan Widaryanti (2019) sebesar 45\%, namun menjadi perhatian bagi orang tua maupun kader posyandu.

5. Gerakan Sukses ASI Eksklusif

Gerakan sukses ASI eksklusif dan makanan sehat bagi ibu menyusu tidak dilaksanakan karena ibu menyusui yang ada di Dusun Karangrejo memiliki bayi $>6$ bulan sehingga masa menyusui secara eksklusif sudah berlalu. Namun demikian pengetahuan untuk meningkatkan jumlah ASI telah disampaikan penyuluhan kepada ibu menyusui dengan materi tentang cara membuat ASI booster alami.

6. Gerakan Masyarakat Hidup Sehat Dengan Pemanfaatan Herbal

Hasil identifikasi keluhan kesehatan yang paling banyak dialami warga Dusun Karangrejo yaitu hipertensi, nyeri sendi dan diabetes mellitus serta batuk pilek dan diare pada anak. Oleh karena itu untuk pemanfaatan herbal difokuskan pada keluhan kesehatan tersebut. Untuk memastikan besarnya masalah kesehatan tersebut, maka sebelum dilaksanakan penyuluhan dan demonstrasi membuat ramuan herbal untuk mengatasi masalah kesehatan dilakukan pemeriksaan hipertensi, gula darah dan kolesterol.

Mayoritas penduduk belum mengetahui cara pengolahan tanaman herbal untuk mengatasi masalah kesehatan ringan yang dialami. Kondisi ini juga ditunjukkan oleh Agil et al (2018) yang menunjukkan lebih dari 50\% peserta pelatihan pengolahan ramuan obat di Desa Wajik, Kabupaten Lamongan Jawa Timur belum mengetahui cara pengolahan pasca panen tanaman obat dan ramuan tanaman obat untuk kesehatan wanita.

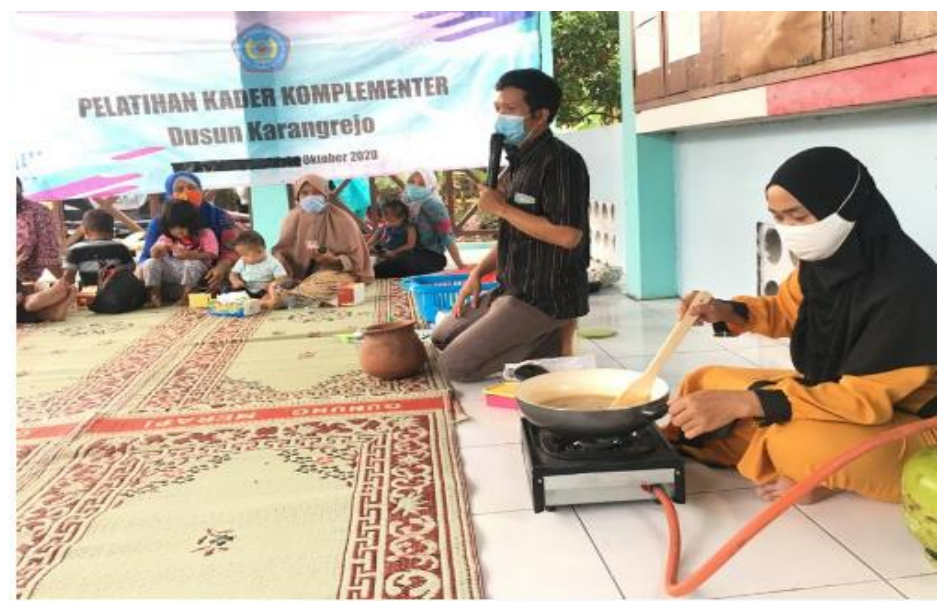

\section{Gambar 6. Penyuluhan Pemanfaatan Herbal untuk Kesehatan}

Proporsi pemanfaatan Tanaman Obat Keluarga (TOGA) pada penduduk semua umur berdasarkan provinsi pada tahun 2018 secara nasional adalah 24,6\%, dan Daerah Istimewa 
Yogyakarta (DIY) memiliki proporsi yang hampir sama (tidak lebih dari 30\%). Oleh karena itu gerakan masyarakat sehat dengan pemanfaatan herbal sangat relevan dengan kondisi masyarakat di DIY khususnya di Dusun Karangrejo. Pendampingan dengan pemberian informasi tentang pengolahan serta manfaat herbal bagi kesehatan sangat penting diberikan kepada masyarakat karena banyak masyarakat beranggapan bahwa suplemen herbal adalah suplemen yang aman untuk dikonsumsi karena berasal dari tanaman. Namun, sebagian besar masyarakat tidak mengetahui bahwa konsentrasi dari senyawa pada suplemen herbal tidak hanya memiliki manfaat tetapi juga memiliki risiko yang berkaitan dengan toksisitas, interaksi obat, maupun efek samping. Melihat manfaat-manfaat tersebut, maka penting bagi kader komplementer dan masyarakat untuk mendapatkan pengetahuan tentang pemanfaatan herbal bagi kesehatan. Hal ini didukung oleh Rahmawati et al (2020) yang menunjukkan bahwa kegiatan sosialisasi pemanfaatan TOGA dapat meningkatkan pemahaman dan pengetahuan untuk lebih memaksimalkan berbagai tanaman obat sebagai pengobatan herbal demi pencegahan dan pengobatan berbagai penyakit secara alami bagi masyarakat Dusun Pimpinga Desa Baturappe Kecamatan Biringbulu Kabupaten Gowa.

\section{KESIMPULAN}

Kesimpulan kegiatan pengabdian kepada masyarakat yang telah dilaksanakan yaitu:

1. Mitra telah membentuk dan memiliki pengurus kampung komplementer.

2. Mitra memiliki kader komplementer yang mempunyai pengetahuan dan keterampilan tentang pijat bayi, MP ASI bahan lokal, ASI booster alami, bekam, accupoint dan terapi herbal.

3. Mitra telah melaksanakan kegiatan kampung komplementer yaitu gerakan makanan sehat untuk bayi, balita dan ibu menyusui serta pemantauan tumbuh kembang bayi dan balita.

\section{UCAPAN TERIMA KASIH / PERSANTUNAN}

Ucapan terima kasih disampaikan kepada Rektor Universitas Respati Yogyakarta yang telah memberikan dukungan pendanaan kegiatan pengabdian masyarakat ini serta Kepala Padukuhan Karangnongko yang telah memberikan izin dan warga Dusun Karangrejo yang telah berpartisipasi aktif dalam kegiatan ini.

\section{DAFTAR PUSTAKA}

Agil M, Wahyuni TS, Studiawan H, Rakhmawati. (2018) Optimalisasi Pemanfaatan Herbal Untuk Kesehatan Masyarakat Desa Wajik Kabupaten Lamongan Provinsi Jawa Timur. Jurnal Pengabdian Kepada Masyarakat 24 (4) https://doi.org/10.24114/jpkm.v24i4.12515.

Arikunto, S. (2018). Dasar-Dasar Evaluasi Pendidikan. Jakarta: PT. Bumi Aksara.

Badan Penelitian dan Pengembangan Kesehatan Kementerian Kesehatan RI. (2019). Riset Kesehatan Dasar Indonesia Tahun 2018. https://kesmas.kemkes.go.id.

Costa, M. (2013). Choosing the Right Assessment Method: Pre-Test/Post-Test Evaluation. Boston: Boston University, Cabrillo Colleges SLO websites 12/17/2013.

Dinas Kesehatan Kabupaten Sleman. (2018). Profil Kesehatan Kabupaten Sleman. Yogyakarta. https://dinkes.slemankab.go.id/wp-content/uploads/2018/09/PROFIL-KESEHATAN-2018-1.pdf

Damayanti NA, Pusparini M, Djannatun T, Ferlianti R. (2017). Metode Pre-Test dan Post-Test Sebagai Salah Satu Alat Ukur Keberhasilan Kegiatan Penyuluhan Kesehatan Tentang Tuberkulosis di Kelurahan Utan Panjang, Jakarta Pusat. Seminar Nasional Penelitian dan Pengabdian pada Masyarakat. (144-150). Bandung: Universitas Islam Bandung. 
Kementerian Kesehatan Republik Indonesia. (2018). Profil Kesehatan Indonesia Jakarta. https://pusdatin.kemkes.go.id/resources/download/pusdatin/profil-kesehatanindonesia/PROFIL_KESEHATAN_2018_1.pdf

Notoatmodjo, S. (2010). Pendidikan dan Perilaku Kesehatan. Jakarta: Rineka Cipta.

Rahmawati., Fatmawati A., Nurhidayat. (2020). Sosialisasi Pemanfaatan Tanaman Obat Keluarga (TOGA) Sebagai Pengobatan Herbal Bagi Masyarakat Dusun Pimpinga Desa Baturappe Kecamatan Biringbulu Kabupaten Gowa. LONTARA ABDIMAS. Jurnal Pengabdian kepada $\begin{array}{llllll}\text { Masyarakat.Volume } & 1 & \text { Nomor } & 2 & \text { Desember } & 2020 .\end{array}$ https//jurnal.poltekesmu.online/abdimas/article/view/53

Subagyo, W., \& Mukhadiono. (2010). Kemampuan Kader dan Partisipasi Masyarakat pada Pelaksanaan Program Posyandu di Karangpucung Purwokerto Selatan. Jurnal Keperawatan Soedirman, 5(2), 74-79. doi:http://dx.doi.org/10.20884/1.jks.2010.5.2.273

Utami, S. (2011). Efektivitas Pendekatan Verbal Secara Individual Oleh Kader Kesehatan Terhadap Ibu Rumah Tangga Dalam Meningkatkan Pengetahuan Deteksi Dini Penyakit Diare Pada Balita Dan Keterampilan Penerapan Terapi Rehidrasi Oral Di Desa Rowobungkul Kecamatan Ngawen Kabupaten Blora Tahun 2011. Universitas Negeri Semarang.

Widaryanti, R. dan Riska, H. (2019). Terapi Komplementer Pelayanan Kebidanan Berdasarkan Bukti Scientific dan Empiris. Yogyakarta: Deepublish.

Widaryanti, R. (2019). Makanan Pendamping ASI Menurunkan Kejadian Stunting pada Balita Kabupaten Sleman. 